\title{
Local Uses of Native Plants in an Area of
(Pernambuco, NE Brazil)
}

\author{
Reinaldo Farias Paiva de Lucena, Viviany \\ Teixeira do Nascimento, Elcida de Lima Araújo \\ and Ulysses Paulino de Albuquerque
}

\section{Research}

\begin{abstract}
The present work sought to identify the utilitarian potential of woody plant species in a fragment of caatinga (semi-arid) vegetation located in the "Agreste" region of Pernambuco State, NE Brazil. The study was undertaken in two stages: a floristic inventory was made of a forest fragment adjacent to the community examined in order to identify the species present in the area; this being followed by an ethnobotanical survey employing semi-structured interviews with 98 informants of both sexes in order to gather information concerning the uses attributed to each of those species. A total of 43 woody species were encountered in the forest fragment area, of which 36 were considered to be useful by the local population. These 36 species were distributed among eight use-categories, among which the most important were fuel, construction, and medicinal uses, with more than 20 species among them. The wood and the bark are the most utilized plant parts, reinforcing the importance that forest products have for the community. The community examined demonstrated a significant knowledge of the woody species in the area that can be used to satisfy local needs, and especially for wooden materials. In spite of the total plant diversity observed, utilitarian potential was concentrated in a reduced number of species demonstrating high relative importance values.
\end{abstract}

\section{Resumo}

O presente trabalho buscou registrar o potencial utilitário das espécies lenhosas de um fragmento de caatinga, localizado na região do Agreste do estado de Pernambuco (Nordeste do Brasil). O estudo foi desenvolvido em duas etapas: na primeira foi feito um inventário florístico em um fragmento de vegetação próximo a comunidade, no intuito de conhecer as espécies presentes na área; e na segunda foi realizado um levantamento etnobotânico, por meio de entrevistas semi-estruturadas, com 98 infor- mantes, homens e mulheres, para se conhecer os usos atribuídos a cada uma das espécies. Foram encontradas no fragmento 43 espécies lenhosas, 36 delas úteis, distribuídas em oito categorias, destacando-se como mais expressivas as categorias combustível, construção e medicinal, com mais de vinte 20 espécies. O tronco e a casca do caule são as partes mais utilizadas reforçando a importância dos recursos madeireiros para a comunidade. A comunidade estudada possui um expressivo conhecimento do uso das espécies lenhosas da área, voltado para o suprimento das necessidades locais, especialmente de produtos madeireiros. Apesar dessa diversidade, o potencial utilitário parece se concentrar em um número reduzido de espécies que apresentaram altos valores de importância relativa.

\section{Introduction}

The caatinga (semi-arid) biome of northeastern Brazil occupies an area of approximately $800,000 \mathrm{~km}^{2}$, and it is typified by a long dry season and irregular rainfall. The caatinga region occupy $11 \%$ of the territory of Brazil

\section{Correspondence}

Ulysses Paulino de Albuquerque, Universidade Federal Rural de Pernambuco, Departamento de Biologia, Área de Botânica. Laboratório de Etnobotânica Aplicada. Dom Manoel de Medeiros s/n. Dois Irmãos, Recife, Pernambuco, BRAZIL upa@ db.ufrpe.br

Ethnobotany Research \& Applications 6:003-013 (2008) 
Ethnobotany Research \& Applications

and has a relatively dense human population of approximately 25 million people (Araújo et al. 2007, Drumond et al. 2000). At least $30 \%$ of this region has already been severely altered through anthropogenic interventions, including the destruction of the native vegetation for pasture formation, agricultural activities, as well as road construction and habitation (Castelletti et al. 2003).

Ethnobotanical surveys within local communities have revealed a tremendous utilitarian and economic potential of the native plant species (Toledo et al. 1995). Important quantitative studies have already been undertaken, covering a wide range of investigations (Aguilar \& Condit 2001, Cunha \& Albuquerque 2006, Mutchnick \& McCarthy 1997, Phillips \& Gentry 1993a,b, Phillips et al. 1994, Tacher et al. 2002, Toledo et al. 1995, Voeks 1996), but few ethnobotanical studies have been published concerning caatinga communities (for example, Albuquerque et al. 2005, 2006, Almeida et al. 2005, Lucena et al. 2007a,b, Monteiro et al. 2006a), and little is actually known about the potential use of the native plant species found there. Most of the recent studies undertaken in the region represented initial efforts to investigate the potential uses of the caatinga vegetation, and to elucidate the use patterns of those natural resources (Araújo et al. 2007).

As such, the present work sought to contribute to the ethnobotanical studies undertaken within the caatinga biome by conducting an inventory of the useful native woody plants in an arboreal caatinga fragment within the state of Pernambuco, Brazil. Our analysis concentrated on local plant uses and the numbers of species citations. Additionally, we attempted to determine if there were differences between wood and non-wood uses of arboreal species, and to establish if certain categories of use are potentially more important in detriment to others.

\section{Materials and Methods}

The work presented here was carried out in the municipality of Caruaru, in the agreste region of Pernambuco

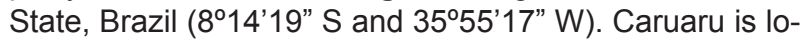
cated $136 \mathrm{~km}$ from the state capital of Recife and has a population of approximately 254,000 inhabitants, $15 \%$ of which live in rural areas (IBGE 2000). The regional climate is semi-arid, and has an average annual temperature of approximately $22^{\circ} \mathrm{C}$. Annual precipitation levels average near $609 \mathrm{~mm}$, and rainfall is usually concentrated in the months of June and July (IBGE 2000).

The study area was located in the "Empresa Pernambucana de Pesquisa Agropecuária" (IPA) experimental station (Pernambuco Agricultural Research Company $8^{\circ} 14^{\prime} 18^{\prime \prime} \mathrm{S}$ and $\left.35^{\circ} 55^{\prime} 20^{\prime \prime} \mathrm{W}\right), 9 \mathrm{~km}$ northwest of the city of Caruaru by way of the PE-095 State Highway (Alcoforado-Filho et al. 2003). The station is located in the Riachão de Malhada de Pedra village at an altitude of $537 \mathrm{~m}$, in an area of 190 ha with an agreste caatinga physiognomy (of which 20 ha are forest). Agricultural experiments are being undertaken at the research station on sorghum (Sorghum sp., Poaceae), corn (Zea mays L., Poaceae), herbaceous cotton (Gossypium sp., Malvaceae), beans (Phaseolus vulgaris L., Fabaceae), potatoes (Solanum tuberosum L., Solanaceae), and Opuntia sp. (Cactaceae) (a species of cactus used as forage), and research efforts include silviculture, food and animal improvement, and natural resource evaluation and usage. The average rainfall at the station is $674.4 \mathrm{~mm} /$ year, based on data from the last 42 years (Empresa Pernambucana de Pesquisa Agropecuária 2003).

In a survey of a 0.6 ha forest tract within the study area, 105 plant species belonging to 43 families were recorded, including herbs, vines, shrubs, and trees (Alcoforado-Filho et al. 2003). The best represented families were Euphorbiaceae (13 species), Mimosaceae (9 species), Fabaceae (7 species), Asteraceae (4 species), and Myrtaceae (4 species). The average plant height was approximately $4.70 \mathrm{~m}$ (maximum $19 \mathrm{~m}$ ) and the average stem diameter $7.2 \mathrm{~cm}$ (maximum $47 \mathrm{~cm}$ ). Alcoforado-Filho et al. (2003) pointed out that even though the area belongs to a state research station, the neighboring communities continue to selectively cut useful species such as Caesalpinia pyramidalis Tul., Solanum sp., Myracrodruon urundeuva Allemão, and Anadenanthera colubrina (Vell.) Brenan. Some of these species (C. pyramidalis and Croton blanchetianus Baill.) are used for firewood as well as for charcoal production (Araújo 1998).

A more detailed description of the study area can be found in the works of Albuquerque et al. (2006), Albuquerque and Oliveira (2007), Florentino et al. (2007), Lucena et al. (2007a,b), Monteiro et al. (2006a,b), and Oliveira et al. (2007).

\section{The community studied}

The community of "Riachão de Malhada de Pedra", investigated in the present study, is located near a forest fragment in the IPA experimental station (Empresa Pernambucana de Pesquisa Agropecuária), in the municipality of Caruaru, Pernambuco State. Cattle raising and subsistence agriculture (especially corn and beans) predominate in this community. Income is principally derived from work offered at the IPA, on larger neighboring farms, or sometimes in Caruaru and other nearby towns. "Riachão de Malhada de Pedra" is located approximately $9 \mathrm{~km}$ from the city of Caruaru, and has 123 residences and approximately 493 inhabitants. This community has been the focus of various systematic ethnobotanical studies during at least four years (Albuquerque et al. 2006, Florentino et al. 2007, Monteiro et al. 2006a,b, Oliveira et al. 2007). The community is established near a 20 hectare fragment of hypoxerophytic arboreal caatinga, which is nominally under the protection of the IPA experimental station. The 


\section{de Lucena et al. - Local Uses of Native Plants in an Area of Caatinga Vegetation (Pernambuco, NE Brazil)}

arboreal component of this forest fragment is dominated by the families Euphorbiaceae, Mimosaceae, and Anacardiaceae, with expressive populations of the species Schinopsis brasiliensis Engler. (Anacardiaceae), C. pyramidalis, M. urundeuva and Maprounea guianensis Aubl. (Alcoforado-Filho et al. 2003).

\section{Floristic Inventory}

Two areas were delimited in forest fragments at the IPA, each with 50 contiguous, semi-permanent $10 \times 10 \mathrm{~m}$ plots (total 100 plots), for a total area of 1 ha. One of the two areas was adjacent to the community, while the other located about $2 \mathrm{~km}$ farther away. The semi-permanent plots were always placed at least $10 \mathrm{~m}$ from the forest boundary in order to minimize edge effects.

All of the woody individuals with a diameter at soil level $(D S L) \geq 3 \mathrm{~cm}$ were surveyed, except for cacti, vines, and small herbaceous plants (Araújo \& Ferraz 2004), and the heights of those plants were recorded. The species collected were identified with the aid of analytical keys, by comparison with material deposited in the Vasconcelos Sobrinho Herbarium (PEUFR) of the Federal Rural University of Pernambuco), and by consultation with specialists. Collected material was mounted and added to the PEUFR herbarium collection.

\section{Ethnobotanical inventory}

Interviews were carried out between January 2003 and July 2004 during visits to 98 of the 123 homes in the community ( 5 family heads chose not to participate; while 14 other houses were either closed or abandoned). The person responsible for the household at the time of the visit was interviewed, regardless of their sex or age. Once the person responsible for the household was identified, a complete explanation of the objectives of the research was made in an effort to obtain that individual's consent to participate in the interviews and data collection procedures. If it was not possible to carry out an interview during an initial visit, up to two more attempts were made. Even so, it was not possible to survey all of the households. Ninety-eight informants were interviewed: 55 men (age 17-81 years) and 43 women (age 19-83 years). This sample included all of the people indicated by the community members themselves as local experts and specialists in the use of the local natural resources. The five household heads that declined to participate in the surveys represented only $4 \%$ of the sample.

The interview form (Albuquerque \& Lucena 2004) included questions concerning the informants' knowledge about the use of regional plants (Albuquerque \& Andrade 2002a,b, Amorozo 2002, Gomez-Beloz 2002, Mutchnick \& McCarthy 1997, Phillips \& Gentry 1993a,b), as well as the individual's social-economic status, schooling, age, profession, monthly income, family composition, time of residence, and marital status. Interviews were conducted individually whenever possible, in an attempt to avoid any direct influences from third parties, and to assure that the data supplied by the informant was as direct and reliable as possible (Phillips \& Gentry 1993a). Interviews were supplemented with other investigative techniques, such as participant observation and guided tours (Albuquerque \& Lucena 2004). Plants cited in the interviews were included in use-categories adapted from Phillips and Gentry (1993b) and Galeano (2000). Subcategories were created within each use-category, and were defined more precisely and objectively as the interviews progressed. The usecategories included: technology, medicines, food, construction, fuel, forage, ethnoveterinary, and others. Species cited for magical-religious, poisonous, and personal hygiene uses were included in the category "other".

\section{Data analysis}

A use-value (UV) was calculated for each species, and use-category employing the following equations: UV = $\sum U_{i} / n, U V_{f}=\sum U V / n_{f}$, and $U V_{c}=\sum U V / n_{c}$, respectively, as modified by Rossato et al. (1999) and Silva and Albuquerque (2004), where: $U_{i}=$ number of uses mentioned by each informant; $n=$ total number of informants; $U V_{f}=$ usevalue for each species in the plant family; $n_{f}=$ number of species in the family; $U_{\mathrm{c}}=$ use-value of each species in the category; $n_{c}=$ number of species in the category. The chi-square test $\left(x^{2}\right)$ was set at a $5 \%$ probability level, and was used to compare the uses of wood and nonwoody products. Differences between the use-categories were compared using the Kruskal-Wallis test based on use-value data. The Spearman correlation coefficient was employed to compare the species citations offered by the men and women interviewed. The use-value technique was chosen as it is considered objective, reproducible, and appropriate for statistical analyses (Hoffman \& Gallaher 2007).

\section{Results}

The floristic survey undertaken in the caatinga forest fragment identified a total of 43 species, or which 36 were considered useful. These species were placed into eight use-categories, with 28 species being included in the fuel category, 26 species in the construction category, 22 species in the category "other", 21 species in the medicinal category, 15 species in the technology category, 14 species in the forage category, 7 species in the ethno-veterinary category, and 5 species in the food category (Figure 1 , Table 1). The average number of uses per species was 5.4 .

A total of 1,428 uses were registered, which represents an average of 14.6 use-citations per informant. Of this total number of use-citations, 944 uses (34 species) were 
Table 1. Woody plants with diameter at soil level $\geq 3 \mathrm{~cm}$ useful for the rural community of "Riachão de Malhada de Pedra", municipality of Caruaru (Pernambuco, Northeast of Brazil). Use categories: $\mathrm{Ct}=$ construction; Fd = food; $\mathrm{FI}=$ fuel; $\mathrm{Fr}=$ forage; $\mathrm{Me}=$ medicine; $\mathrm{Ot}=$ other; $\mathrm{Tc}=$ technology, $\mathrm{Vt}=$ veterinary. Parts used: $\mathrm{Ap}=$ all $\mathrm{part} ; \mathrm{Ba}=\mathrm{bark} ; \mathrm{Eb}=$ embryo; $\mathrm{FI}=$ flower; $\mathrm{Fr}=$ fruit; $\mathrm{lb}=$ inner bark; $\mathrm{La}=$ latex; $\mathrm{Lf}=$ leaf; $\mathrm{Re}=$ resin; $\mathrm{Ro}=$ root; $\mathrm{Se}=\mathrm{seed}$; $\mathrm{Tk}=\mathrm{trunk}$.

\begin{tabular}{|c|c|c|c|c|}
\hline Family/Species & Common name & Voucher & Uses & Part (s) used \\
\hline \multicolumn{5}{|l|}{ Anacardiaceae } \\
\hline Myracrodruon urundeuva Allemão & Aroeira & 46171 & $\mathrm{Ct}, \mathrm{FI}, \mathrm{Fr}, \mathrm{Me}, \mathrm{Ot}, \mathrm{Vt}$ & $\mathrm{Ba}, \mathrm{lb}, \mathrm{Lf}, \mathrm{Ro}, \mathrm{Tk}$ \\
\hline Schinopsis brasiliensis Engl. & Brauna & 47988 & $\mathrm{Ct}, \mathrm{Fl}, \mathrm{Fr}, \mathrm{Me}, \mathrm{Ot}, \mathrm{Tc}$ & $\mathrm{Ba}, \mathrm{Ib}, \mathrm{Fr}, \mathrm{Re}, \mathrm{Tk}$ \\
\hline \multicolumn{5}{|l|}{ Bombacaceae } \\
\hline Chorisia glaziovii Santos & Barriguda & 48189 & $\mathrm{Me}, \mathrm{Ot}$ & Lf, Fr \\
\hline \multicolumn{5}{|l|}{ Boraginaceae } \\
\hline $\begin{array}{l}\text { Cordia trichotoma (Vel.) } \\
\text { Arráb. ex Steud. }\end{array}$ & Frei Jorge & 44266 & $\mathrm{Ct}, \mathrm{FI}, \mathrm{Ot}, \mathrm{Tc}$ & Tk \\
\hline Cordia globosa (Jacq.) Kunth & Maria Preta & 44238 & $\mathrm{Ct}, \mathrm{FI}, \mathrm{Ot}$ & Tk \\
\hline \multicolumn{5}{|l|}{ Burseraceae } \\
\hline $\begin{array}{l}\text { Commiphora leptophloeos } \\
\text { (Mart.) J.B.Gillett }\end{array}$ & Umburana & 43840 & $\mathrm{Ct}, \mathrm{Fl}, \mathrm{Fr}, \mathrm{Me}, \mathrm{Ot}, \mathrm{Tc}$ & Ap, Fr, La, Lf, Tk \\
\hline \multicolumn{5}{|l|}{ Caesalpiniaceae } \\
\hline Bauhinia cheilantha (Bong.) Steud. & Mororó & 43839 & $\mathrm{Ct}, \mathrm{Fl}, \mathrm{Me}$ & Fl, Lf, Tk \\
\hline Caesalpinia pyramidalis Tul. & Catingueira & 44239 & $\mathrm{Ct}, \mathrm{FI}, \mathrm{Me}, \mathrm{Ot}$ & $\mathrm{Ap}, \mathrm{Ba}, \mathrm{Fl}, \mathrm{Lf}, \mathrm{Ro}, \mathrm{Tk}$ \\
\hline \multicolumn{5}{|l|}{ Capparaceae } \\
\hline Capparis jacobinae Moric. ex Eichler. & Incó & 43823 & $\mathrm{Fd}, \mathrm{FI}, \mathrm{Fr}, \mathrm{Me}, \mathrm{Tc}$ & $\mathrm{Ba}, \mathrm{Fr}, \mathrm{Tk}$ \\
\hline Capparis hastatta Jacq. & Feijão-de-boi & 43822 & $\mathrm{Ct}, \mathrm{FI}, \mathrm{Fr}, \mathrm{Tc}$ & Lf, Tk \\
\hline \multicolumn{5}{|l|}{ Clusiaceae } \\
\hline Clusia sp. & Gameleira & 45765 & $\mathrm{FI}, \mathrm{Ot}$ & Tk \\
\hline \multicolumn{5}{|l|}{ Euphorbiaceae } \\
\hline Croton argyroglossus Baill. & Velame Branco & 44267 & $\mathrm{FI}, \mathrm{Me}$ & Ba, Lf, Ro, Tk \\
\hline Croton blanchetianus Baill. & Marmeleiro & 43833 & $\begin{array}{l}\text { Ct, FI, Fr, Me, } \\
\text { Ot, Tc, Vt }\end{array}$ & $\mathrm{Ba}, \mathrm{Lf}, \mathrm{Ro}, \mathrm{Se}, \mathrm{Tk}$ \\
\hline Croton rhamnifolius Willd. & Velame & 43804 & $\mathrm{Ct}, \mathrm{FI}, \mathrm{Fr}, \mathrm{Me}, \mathrm{Ot}, \mathrm{Tc}$ & $\mathrm{Ba}, \mathrm{Lf}, \mathrm{Se}, \mathrm{Tk}$ \\
\hline Jatropha curcas L. & Pinhão Manso & 43838 & $\mathrm{Me}, \mathrm{Ot}, \mathrm{Vt}$ & Ap, Eb, Se, Tk \\
\hline Jatropha mollissima (Pohl) Baill. & Pinhão Brabo & 43809 & $\mathrm{Ct}, \mathrm{Me}, \mathrm{Ot}, \mathrm{Vt}$ & Ap, La, Se, Tk \\
\hline Manihot cf. dichotoma Ule. & Maniçoba & 43816 & Ct, Ot & Fl, Lf, Tk \\
\hline $\begin{array}{l}\text { Sapium lanceolatum } \\
\text { (Mull. Arg.) Huber. }\end{array}$ & Burra Leiteira & 45746 & $\mathrm{Ct}, \mathrm{Fr}, \mathrm{Ot}$ & Fr, La, Tk \\
\hline $\begin{array}{l}\text { Sebastiana jacobinensis } \\
\text { (Müll. Arg.) Müll. Arg. }\end{array}$ & Leiteiro & 44245 & $\mathrm{Ct}, \mathrm{FI}, \mathrm{Me}, \mathrm{Tc}$ & $\mathrm{Ba}, \mathrm{Tk}$ \\
\hline \multicolumn{5}{|l|}{ Malpighiaceae } \\
\hline Malpighiaceae 1 & Rama Branca & & $\mathrm{Ct}, \mathrm{FI}, \mathrm{Tc}$ & Tk \\
\hline \multicolumn{5}{|l|}{ Meliaceae } \\
\hline Cedrela odorata L. & Cedro & 44265 & $\mathrm{Ct}, \mathrm{Me}, \mathrm{Ot}, \mathrm{Tc}$ & Ap, Ba, Tk \\
\hline \multicolumn{5}{|l|}{ Mimosaceae } \\
\hline Acacia sp. & Rapadura & 45766 & $\mathrm{FI}$ & Tk \\
\hline Acacia farnesiana (L.) Willd. & Jurema Branca & 44262 & $\mathrm{Ct}, \mathrm{FI}, \mathrm{Me}, \mathrm{Ot}$ & Tk \\
\hline Acacia paniculata Willd. & Unha-de-gato & 43811 & $\mathrm{FI}, \mathrm{Fr}, \mathrm{Ot}$ & Ib, Lf, Tk \\
\hline
\end{tabular}


Vegetation (Pernambuco, NE Brazil)

\begin{tabular}{|c|c|c|c|c|}
\hline Family/Species & Common name & Voucher & Uses & Part (s) used \\
\hline Acacia piauhienses Benth. & $\begin{array}{l}\text { Calombi } \\
\text { Branco }\end{array}$ & 44241 & $\mathrm{Ct}, \mathrm{FI}, \mathrm{Ot}$ & Tk \\
\hline $\begin{array}{l}\text { Anadenanthera colubrina } \\
\text { (Vell.) Brenan var. cebil }\end{array}$ & Angico & 43824 & $\begin{array}{l}\text { Ct, FI, Fr, Me, } \\
\text { Ot, Tc, Vt }\end{array}$ & $\mathrm{Ba}, \mathrm{Ib}, \mathrm{Fl}, \mathrm{Fr}, \mathrm{Tk}$ \\
\hline Parapiptadenia sp. & Miguel Correia & 45771 & $\mathrm{Ct}, \mathrm{FI}, \mathrm{Ot}$ & Ap, Tk \\
\hline $\begin{array}{l}\text { Piptadenia stipulacea } \\
\text { (Benth.) Ducke. }\end{array}$ & Calombi & 44268 & $\mathrm{Ct}, \mathrm{FI}, \mathrm{Fr}$ & Lf, Tk \\
\hline \multicolumn{5}{|l|}{ Myrtaceae } \\
\hline Eugenia sp. & Batinga & 46128 & $\mathrm{Ct}, \mathrm{Fd}, \mathrm{Fl}, \mathrm{Fr}$ & Fr, Tk \\
\hline Eugenia uvalha Cambess. & Ubaia & 45773 & $\mathrm{Ct}, \mathrm{Fd}, \mathrm{FI}, \mathrm{Fr}, \mathrm{Tc}$ & Fr, Tk \\
\hline Myrciaria sp. & Jaboticaba & 45774 & $\mathrm{Ct}, \mathrm{Fl}, \mathrm{Fr}, \mathrm{Me}, \mathrm{Tc}$ & $\mathrm{Ba}, \mathrm{Ec}, \mathrm{FI}, \mathrm{Fr}, \mathrm{Tk}$ \\
\hline \multicolumn{5}{|l|}{ Nyctaginaceae } \\
\hline Guapira laxa (Netto) Furlan & Piranha & 44264 & $\mathrm{Ct}, \mathrm{FI}, \mathrm{Fr}, \mathrm{Me}, \mathrm{Tc}$ & $\mathrm{Ba}, \mathrm{Fl}, \mathrm{Tk}$ \\
\hline \multicolumn{5}{|l|}{ Rhamnaceae } \\
\hline Ziziphus joazeiro Mart. & Juazeiro & 45761 & $\mathrm{Ct}, \mathrm{Fd}, \mathrm{Fl}, \mathrm{Me}, \mathrm{Vt}$ & Ba, Fr, Lf, Tk \\
\hline \multicolumn{5}{|l|}{ Solanaceae } \\
\hline Capsicum parvifolium Sendtn. & Pimentinha & 43844 & $\mathrm{FI}, \mathrm{Fr}, \mathrm{Tc}$ & $\mathrm{Fl}, \mathrm{Fr}, \mathrm{Se}, \mathrm{Tk}$ \\
\hline \multicolumn{5}{|l|}{ Verbenaceae } \\
\hline Lantana camara L. & Chumbinho & 43851 & $\mathrm{FI}, \mathrm{Me}$ & FI, Lf, Se, Tk \\
\hline Lippia sp. & Camarazinha & 46124 & $\mathrm{Me}, \mathrm{Tc}$ & $\mathrm{Fl}, \mathrm{Tk}$ \\
\hline
\end{tabular}

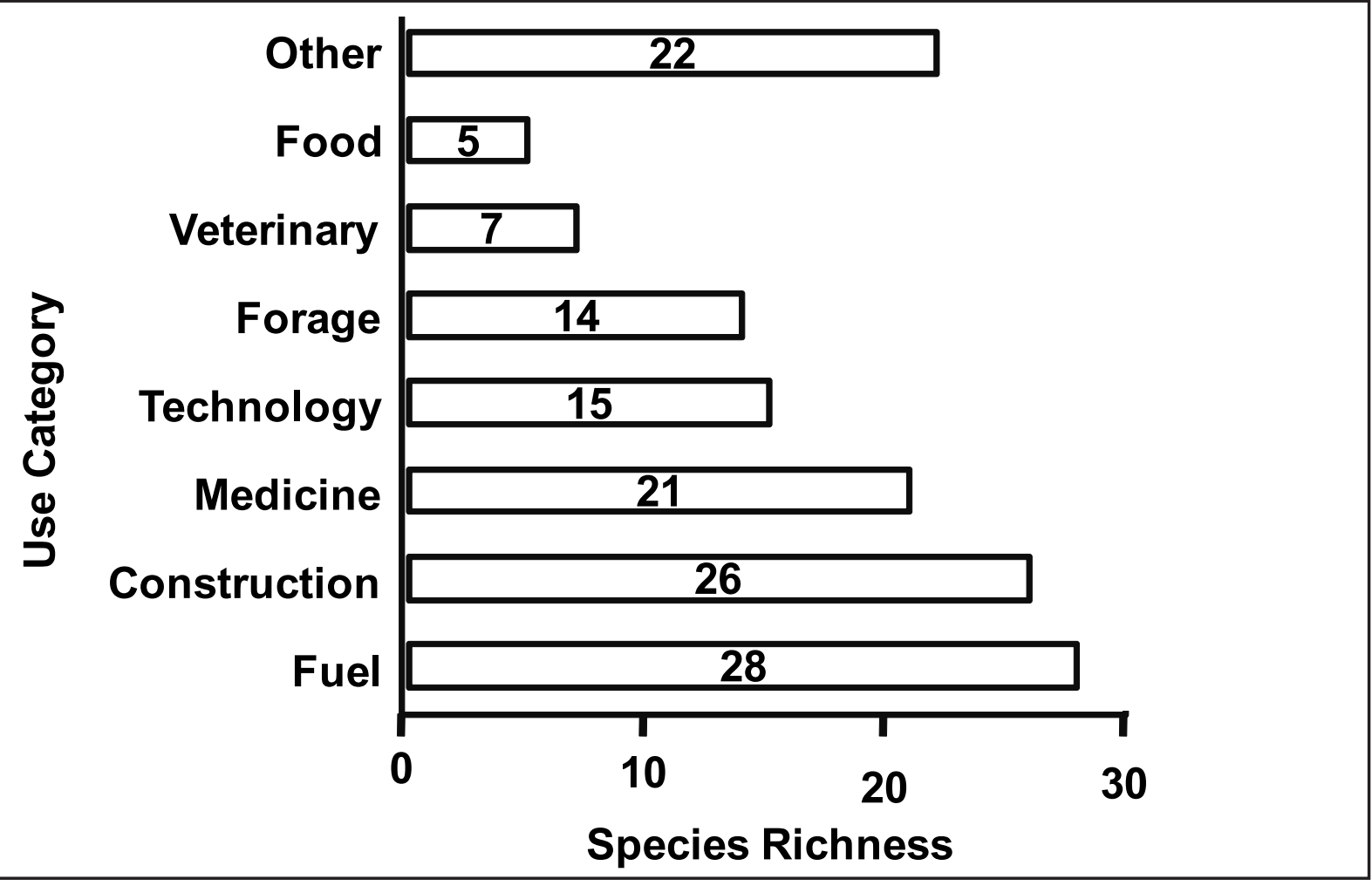

Figure 1. Distribution of species richness in the different use-categories in the "Riachão de Malhada de Pedra" community, municipality of Caruaru (Pernambuco, NE Brazil). 
wood uses, and 484 uses (29 species) considered nonwood uses, representing a statistically significant difference $\left(x^{2}=3.93, p<0.05\right)$. The trunk is the plant part most used by the community $(68.17 \%)$, followed by the bark $(20.74 \%)$, and the leaves $(4.7 \%)$. The products obtained from the tree trunk account for up to $90.2 \%$ of all citations, including resin and latex.

Use-citations are reported in Table 2. When comparing use-categories by the number of species and the number of citations, it could be observed that the medicinal, fuel, construction, and technology categories stood out in relation to the rest, either in terms of the number of species or in terms of the number of use-citations.

Table 2. Number of species and use-citations for the usecategories as determined in the "Riachão de Malhada de Pedra" community, municipality of Caruaru (Pernambuco State, NE Brazil).

\begin{tabular}{|l|c|c|}
\hline Use Category & $\begin{array}{c}\text { Number of } \\
\text { Species }\end{array}$ & $\begin{array}{c}\text { Number of } \\
\text { Citations (\%) }\end{array}$ \\
\hline Fuel & 28 & $416(29.1)$ \\
\hline Construction & 26 & $392(27.4)$ \\
\hline Medicine & 21 & $316(22.1)$ \\
\hline Technology & 15 & $131(9.2)$ \\
\hline Forage & 14 & $27(1.9)$ \\
\hline Veterinary & 7 & $17(1.2)$ \\
\hline Food & 5 & $23(1.6)$ \\
\hline Other & 22 & $106(7.5)$ \\
\hline $\begin{array}{l}\text { Quotations } \\
\text { total }\end{array}$ & 36 & $1428(100)$ \\
\hline \multicolumn{2}{|c|}{$\mathrm{X}^{2}=69.29, \mathrm{p}<0.001$} \\
\hline
\end{tabular}

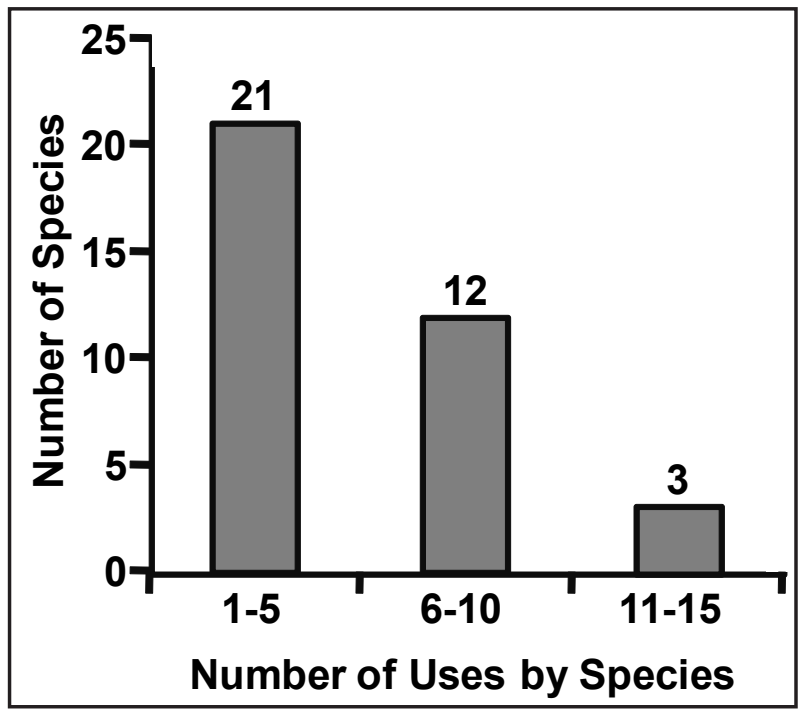

Figure 2. Number of uses attributed to each species in the "Riachão de Malhada de Pedra" community, municipality of Caruaru (Pernambuco State, NE Brazil).

Most species (21) had from 1 to 5 uses, such as Chorisia glaziovii, Clusia sp., Manihot cf. dichotoma, and Lantana camara. Twelve species had 6 to 10 indicated uses, such as Eugenia uvalha and Ziziphus joazeiro (Figure 2). The most versatile species, in terms of the number of uses, were A. colubrina var. cebil and Schinopsis brasiliensis, with 13 and 12 cited uses, respectively. In addition, these same species have a wide variety of useful parts (5).

The most cited species were A. colubrina (261 citations), M. urundeuva (182 citations), S. brasiliensis (136 citations), and C. pyramidalis (119 citations) (Table 3 ). However, the most versatile species in terms of the variety of plant parts used was $C$. pyramidalis. The bark, flower, leaf, wood, root, and "the whole plant" of this species are

Table 3. Number of citations and the use-values of useful woody species in the rural community of "Riachão de Malhada de Pedra", municipality of Caruaru (Pernambuco State, NE Brazil).

\begin{tabular}{|c|c|c|c|c|}
\hline \multirow{2}{*}{$\begin{array}{l}\text { Family/Species } \\
\text { Species }\end{array}$} & \multicolumn{2}{|c|}{ Citations } & \multirow[t]{2}{*}{ Total } & \multirow{2}{*}{$\begin{array}{l}\text { Total use- } \\
\text { value UV }\end{array}$} \\
\hline & Men & Women & & \\
\hline \multicolumn{5}{|l|}{ Anacardiaceae } \\
\hline Myracroduon urundeuva Allemão & 83 & 99 & 182 & 1.85 \\
\hline Schinopsis brasiliensis Engl. & 80 & 56 & 136 & 1.38 \\
\hline \multicolumn{5}{|l|}{ Bombacaceae } \\
\hline Chorisia glaziovii (O. Kuntze) E. Santos. & 6 & 4 & 10 & 0.10 \\
\hline \multicolumn{5}{|l|}{ Boraginaceae } \\
\hline Cordia trichotoma (Vel.) Arráb. ex Steud. & 14 & 16 & 30 & 0.30 \\
\hline Cordia globosa (Jacq.) Humb., Bompl. \& Kunth. & 5 & 3 & 8 & 0.08 \\
\hline \multicolumn{5}{|l|}{ Burseraceae } \\
\hline Commiphora leptophloeos (Mart.) J. B. Gillet. & 30 & 19 & 49 & 0.5 \\
\hline
\end{tabular}


de Lucena et al. - Local Uses of Native Plants in an Area of Caatinga

Vegetation (Pernambuco, NE Brazil)

\begin{tabular}{|c|c|c|c|c|}
\hline \multirow{2}{*}{\begin{tabular}{|l|} 
Family/Species \\
Species
\end{tabular}} & \multicolumn{2}{|c|}{ Citations } & \multirow[t]{2}{*}{ Total } & \multirow{2}{*}{\begin{tabular}{|l} 
Total use \\
value UV
\end{tabular}} \\
\hline & Men & Women & & \\
\hline Bauhinia cheilantha (Bong.) Steud. & 45 & 32 & 77 & 0.78 \\
\hline Caesalpinia pyramidalis Tul. & 65 & 54 & 119 & 1.21 \\
\hline \multicolumn{5}{|l|}{ Capparaceae } \\
\hline Capparis jacobinae Moric. & 11 & 1 & 12 & 0.12 \\
\hline Capparis hastata L. & 40 & 27 & 67 & 0.68 \\
\hline \multicolumn{5}{|l|}{ Clusiaceae } \\
\hline Clusia sp. & 2 & 0 & 2 & 0.02 \\
\hline \multicolumn{5}{|l|}{ Euphorbiaceae } \\
\hline Croton argyroglossum Baill. & 8 & 0 & 8 & 0.08 \\
\hline Croton blanchetianus Baill. & 46 & 28 & 74 & 0.75 \\
\hline Croton rhamnifolius Kunth. & 11 & 7 & 18 & 0.18 \\
\hline Jatropha curcas L. & 7 & 3 & 10 & 0.10 \\
\hline Jatropha mollissima (Pohl) Baill. & 16 & 18 & 34 & 0.34 \\
\hline Manihot cf. dichotoma Ule. & 4 & 4 & 8 & 0.08 \\
\hline Sapium lanceolatum (Mull. Arg.) Huber. & 21 & 9 & 30 & 0.30 \\
\hline Sebastiana jacobinensis (Mull. Arg.) Mull. Arg. & 4 & 1 & 5 & 0.05 \\
\hline \multicolumn{5}{|l|}{ Malpighiaceae } \\
\hline Malpighiaceae 1 & 11 & 1 & 12 & 0.12 \\
\hline \multicolumn{5}{|l|}{ Meliaceae } \\
\hline Cedrela odorata L. & 15 & 7 & 22 & 0.22 \\
\hline \multicolumn{5}{|l|}{ Mimosaceae } \\
\hline Acacia sp. & 2 & 1 & 3 & 0.03 \\
\hline Acacia farnesiana (L.) Willd. & 12 & 3 & 15 & 0.15 \\
\hline Acacia paniculata Willd. & 14 & 9 & 23 & 0.23 \\
\hline Acacia piauhienses Benth. & 24 & 18 & 42 & 0.42 \\
\hline Anadenanthera colubrina (Vell.) Brenam. & 134 & 127 & 261 & 2.66 \\
\hline Parapiptadenia sp. & 6 & 2 & 8 & 0.08 \\
\hline Piptadenia stipulacea (Benth.) Ducke. & 22 & 16 & 38 & 0.38 \\
\hline \multicolumn{5}{|l|}{ Myrtaceae } \\
\hline Eugenia sp. & 7 & 1 & 8 & 0.08 \\
\hline Eugenia uvalha Camb. & 18 & 1 & 19 & 0.19 \\
\hline Myrciaria sp. & 21 & 8 & 29 & 0.29 \\
\hline \multicolumn{5}{|l|}{ Nyctaginaceae } \\
\hline Guapira laxa (Netto) Furlan. & 10 & 9 & 19 & 0.19 \\
\hline \multicolumn{5}{|l|}{ Rhamnaceae } \\
\hline Ziziphus joazeiro Mart. & 39 & 41 & 80 & 0.81 \\
\hline \multicolumn{5}{|l|}{ Solanaceae } \\
\hline Capsicum parvifolium Sendtm. & 5 & 4 & 9 & 0.09 \\
\hline \multicolumn{5}{|l|}{ Verbenaceae } \\
\hline Lantana camara L. & 8 & 5 & 13 & 0.13 \\
\hline Lippia sp. & 3 & 0 & 3 & 0.03 \\
\hline
\end{tabular}


used (total of six parts). These uses are distributed among four categories: forage, construction, medicinal, and "other" uses. The next most versatile species in terms of plant parts used, with 5 parts each, were: $C$. blanchetianus ( 7 use-categories), $M$. urundeuva (6 use-categories), $S$. brasiliensis (6 use-categories), Commiphora leptophloeos (Mart.) J. B. Gillet (5 use-categories), A. colubrina (5 usecategories), and Myrciaria sp. (5 use-categories). Thus, although $C$. pyramidalis is one of the most versatile species, it is not among the species with the most use-citations. All of these species are listed in more than five use-categories, among which the construction, fuel, and medicinal categories stand out as the most important. This species order is very similar when men's and women's citations are compared, and the correlation analysis demonstrates that the species with the most overall citations were also those most cited by men and women separately $(r=0.96$, $p<0.001)$.

Six use-value classes were established, with amplitude intervals of 0.5 . Class 1 comprises use-values between 0 and 0.5 ; class 2 , from 0.6 to 1 ; class 3 , from 1.1 to 1.5 , class 4 , from 1.6 to 2 ; class 5 , from 2.1 to 2.5 ; and class 6 , from 2.6 to 3. Seventy-eight percent of the species are included in class 1 , and $11 \%$ in class 2 . Only one species (M. urundeuva) had a use-value in the class 4 range, and only one species ( $A$. colubrina) had a use-value in the class 6 range. No species demonstrated a use-value in the class 5 range. Species distribution by use-value class is shown in Figure 3 and use-value by species is shown in Table 3 . When comparing the average use-values per category, the veterinary category has the highest average $(0.96)$, followed by forage (0.67) medicinal (0.56), construction (0.54), "other" (0.54), technology (0.50), fuel (0.48), and food (0.30) (Ta-

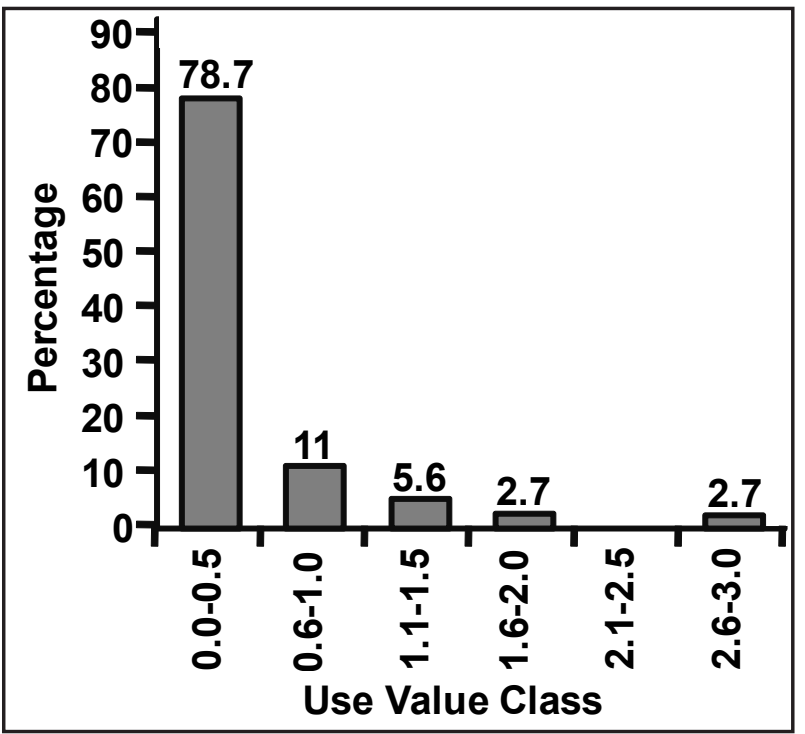

Figure 3. Percentage of species in each of the use-value classes in the "Riachão de Malhada de Pedra" community, municipality of Caruaru (Pernambuco State, NE Brazil).

bles 4). Nevertheless, the Kruskal-Wallis test did not detect significant differences between these averages.

\section{Discussion}

The community examined in this study was aware of the potential use of a majority of the woody species available locally, and demonstrated a strong bias towards wood uses. We had originally expected to find that certain categories were potentially more useful than others (in terms of the use-values assigned to them), but this was not in

Table 4. Use-value by use categories as determined in the "Riachão de Malhada de Pedra" community, municipality of Caruaru (Pernambuco State, NE Brazil).

\begin{tabular}{|l|l|l|l|}
\hline $\begin{array}{l}\text { Use } \\
\text { Category* }\end{array}$ & $\begin{array}{l}\text { Use Value } \\
\text { Average } \pm \\
\text { Standard } \\
\text { deviation }\end{array}$ & $\begin{array}{l}\text { Number } \\
\text { of } \\
\text { Species }\end{array}$ & Important Species \\
\hline Food & $0.30 \pm 0.29$ & 5 & Ziziphus joazeiro \\
\hline Fuel & $0.48 \pm 0.62$ & 28 & Myracrodruon urundeuva, Schinopsis brasiliensis, Caesalpinia pyramidalis \\
\hline Construction & $0.54 \pm 0.62$ & 26 & $\begin{array}{l}\text { Anadenanthera colubrina, Myracrodruon urundeuva, } \\
\text { Schinopsis brasiliensis }\end{array}$ \\
\hline Veterinary & $0.96 \pm 0.95$ & 7 & Anadenanthera colubrina \\
\hline Forage & $0.67 \pm 0.77$ & 14 & $\begin{array}{l}\text { Anadenanthera colubrina, Myracrodruon urundeuva, } \\
\text { Schinopsis brasiliensis }\end{array}$ \\
\hline Medicine & $0.56 \pm 0.69$ & 21 & $\begin{array}{l}\text { Anadenanthera colubrina, Myracrodruon urundeuva, } \\
\text { Schinopsis brasiliensis }\end{array}$ \\
\hline Technology & $0.50 \pm 0.69$ & 15 & Anadenanthera colubrina, Schinopsis brasiliensis \\
\hline Other & $0.54 \pm 0.67$ & 22 & $\begin{array}{l}\text { Anadenanthera colubrina, Myracrodruon urundeuva, } \\
\text { Caesalpinia pyramidalis }\end{array}$ \\
\hline
\end{tabular}

${ }^{*}$ Differences between categories were not significant at a $5 \%$ probability level using the Kruskal-Wallis test. 


\section{de Lucena et al. - Local Uses of Native Plants in an Area of Caatinga Vegetation (Pernambuco, NE Brazil)}

fact seen, probably because any given species would contribute its use-value to a number of different categories - for a majority of the plants had multiple uses. The predominance of the use of the wood itself (the trunk of the tree), and the bark and stems, reinforced the importance of these tree resources represent to the community studied (see Albuquerque 2006). Emphasis on these plant parts was also reported by Galeano (2000) in Colombia, Tacher et al. (2002) in Mexico, Dalle and Potvin (2004) in Panama, and by Cunha and Albuquerque (2006) in Brazil. The total numbers of species registered in these studies are very similar to those encountered in surveys undertaken in the caatinga region (Albuquerque et al. 2005, Ferraz et al. 2005). Ferraz et al. (2005), for example, registered 31 useful native species, with the forage category demonstrating the largest number of species cited (19). In the community examined in the present work, however, forage was not an overly category, with only 14 species being cited.

We encountered a predominant number of useful species in the categories of fuels, construction, and medicine, a tendency observed in other regions (Aguilar \& Condit 2001, Cunha \& Albuquerque 2006, Louga et al. 2000, Lucena et al. 2007a, Tacher et al. 2000, Voeks 1996). Wood uses fulfill the needs of the local communities in regards to numerous products, and the impact of these uses will need to be carefully measured and analyzed. Traditional methods of collecting data in ethnobotanical studies that are based on carrying out interviews do not generally give a faithful picture of the true use of the plants in a given reagion, or of the impact resulting from that use, as people may cite plants that they do not actually use (Albuquerque \& Lucena 2005).

We observed an apparently high number of use-citations attributed to the 36 useful species identified, although the average number of citations offered by the individual interviewees was low (14.6) when compared to the study of Ferraz et al. (2005), for example, which reported an average of 28.6 citations per informant. This suggests that although the Riachão community is aware of the potential uses of the species examined, the community members either attributed only a small number of use-citations to them or knowledge concerning their potential uses was not uniformly distributed among those people.

The species Schinopsis brasiliensis and Anadenanthera colubrina var. cebil demonstrated the greatest numbers of different types of uses, indicating the significant versatility of these plants. Another important point revealed in the present analysis was that $S$. brasiliensis is gradually being substituted by commercially available wood products. A similar situation that was not observed with $A$. colubrina, as this species is still widely used in fence construction (Nascimento 2007) and in the production of fuelwood and charcoal (Ramos et al. 2008a,b).
An analysis of use-pressure on a given species requires studies that collect information about actual use, the quantities of that resource that are collected, and the frequency of their collection. It is important to point out that the usevalue technique employed in the present study can often over-estimate the value of a species, as has been demonstrated by Albuquerque et al. (2006). As such, we limited ourselves here to interpreting it as a measure of utilitarian potential.

A majority of the useful species in the study area demonstrated low use-values, indicating that many uses are concentrated among just a few species, a phenomenon that has been observed in many studies with the same type of focus (Albuquerque et al. 2005, Cunha \& Albuquerque 2006, Ferraz et al. 2006, Galeano 2000). The high average use-values attributed to categories comprising only a few species may be explained by the fact that these categories are composed of species with high individual usevalues, such as $A$. colubrina and $M$. urundeuva.

The studied species appear to be most used in satisfying local necessities, principally for wood products. Our examination of the use-value indicates that:

1) A small group of species in the study area concentrated a significant fraction of the total observed utilitarian potential. Albuquerque and Oliveira (2007) proposed the utilitarian redundancy model to examine if the presence of various species with the same uses affected their conservation. In general, our data indicates that a small number of species are locally preferred and do receive considerably more attention than others - a situation that can have immediate conservation implications

2) Species with greater use-values are highly versatile in terms of their use-potential, and the harvesting of forest wood products must be evaluated using information concerning real use and actual demand. The certainty of the real use of these products is extremely important for establishing conservation strategies in the region, as Lucena et al. (2007a) have pointed out that caatinga plants normally have multiple uses (see also Oliveira et al. 2007). Additionally, there are real differences in the repertoire of plants known to a community and those that they actually use (Albuquerque 2006). Local populations with access to seasonal dry forests (such as those found in the caatinga) appear to favor the use of woody species (especially the stem and branches), as suggested by the seasonal climatic hypothesis (Albuquerque 2006).

\section{Acknowledgements}

The authors would like to thank the "Empresa Pernambucana de Pesquisa Agropecuária (IPA)" in Caruaru, Pernambuco for logistic support at their experimental station; CNPq for financial support and grants given to U.P. Albu- 
querque; CAPES for the bursary given to the first author; the informants of the community studied for their hospitality and solicitude; the Federal Rural University of Pernambuco.

\section{Literature Cited}

Albuquerque, U.P. 2006. Re-examining hypotheses concerning the use and knowledge of medicinal plants: a study in the Caatinga vegetation of NE, Brazil. Journal of Ethnobiology and Ethnomedicine 2.

Albuquerque, U.P. \& L.H.C. Andrade. 2002a. Conhecimento botânico tradicional e conservação em uma área de caatinga no Estado de Pernambuco, Nordeste do Brasil. Acta Botanica Brasilica 16:273-285.

Albuquerque, U.P. \& L.H.C. Andrade. 2002b. Uso de recursos vegetais da caatinga: o caso do agreste do estado de Pernambuco (Nordeste do Brasil). Interciencia 27:36345.

Albuquerque, U.P. \& R.F.P. Lucena. 2004. Métodos e técnicas para a coleta de dados. Pp. 37-62 in Métodos e técnicas na pesquisa etnobotânica. Edited by U.P. Albuquerque \& R.F.P. Lucena. Editora NUPEEA. Recife, Brasil.

Albuquerque, U.P., L.H.C. Andrade \& A.C.O. Silva. 2005. Use of plant resources in a seasonal dry forest (Northeastern Brazil). Acta Botanica Brasílica 19:27-38.

Albuquerque, U.P. \& R.F.P. Lucena. 2005. Can apparency affect the use of plants by local people in tropical forests? Interciencia 30:506-511.

Albuquerque, U.P., R.F.P. Lucena, J.M. Monteiro, A.T.N. Florentino and C.F.C.B.R. Almeida. 2006. Evaluating two quantitative ethnobotanical techniques. Ethnobotany Research \& Applications 4:51-60.

Albuquerque, U.P. \& R.F. Oliveira. 2007. Is the use-impact on native caatinga species in Brazil reduced by the high species richness of medicinal plants? Journal of Ethnopharmacology 113:156-170.

Alcoforado-Filho, F.G., E.V.S.B. Sampaio \& M.J.N. Rodal. 2003. Florística e fitossociologia de um remanescente de vegetação caducifólia espinhosa arbórea em Caruaru, Pernambuco. Acta Botanica Brasilica 17:287-303.

Almeida, C.F.C.B.R., T.C.L. Silva, E.L.C. Amorin, M.B.S. Maia \& U.P. Albuquerque. 2005. Life strategy and chemical composition as predictors of the selection of medicinal plants from the caatinga (Northeast Brazil). Journal of Arid Environments 62:127-142.
Aguilar, S. \& R. Condit. 2001. Use of native tree species by a Hispanic community in Panama. Economic Botany 55:223-235.

Amorozo, M.C.M. 2002. Uso e diversidade de plantas medicinais em Santo Antônio do Leverger, MT, Brasil. Acta Botanica Brasilica 16:189-203.

Araújo, E.L. 1998. Aspectos da dinâmica populacional de duas espécies em floresta tropical seca (caatinga), Nordeste do Brasil. Tese (Doutorado), Universidade Estadual de Campinas, Campinas - São Paulo.

Araújo, E.L. \& E.M.N. Ferraz. 2004. Amostragem da vegetação e índices de diversidade. Pp. 89-137 in Métodos e técnicas na pesquisa etnobotânica. Edited by U.P. Albuquerque \& R.F.P. Lucena. Editora NUPEEA. Recife, Brasil.

Araújo, E.L., C.C. Castro \& U.P. Albuquerque. 2007. Dynamics of Brazilian Caatinga - a review concerning the plants, environment and people. Functional Ecosystems and Communities 1:15-29.

Castelletti, C.H.M., J.M.C. Silva, M. Tabarelli \& A.M.S. Santos. 2003. Quanto ainda resta da caatinga? Uma estimativa preliminar. Pp. 719-734 in Ecologia e conservação da Caatinga. Edited by I.R. Leal, M. Tabarelli M \& J.M.C. Silva. Editora Universitária da UFPE. Recife, Brasil.

Cunha, L.V.F. \& U.P. Albuquerque. 2006. Quantitative ethnobotany in an Atlantic Forest fragment of Northeastern Brazil - implications to conservation. Environmental Monitoring and Assessment 114:1-25.

Dalle, S.P. \& C. Potvin. 2004. Conservation of useful plants: An evaluation of local priorities from two indigenous communities in eastern Panama. Economic Botany 58:38-57.

Drumond, M.A., L.H.P. Kiill, P.C.F. Lima, M.C. Oliveira, V.R. Oliveira, S.G. Albuquerque, C.E.S. Nascimento \& J. Cavalcanti. 2000. in Estratégias para o Uso Sustentável da Biodiversidade da Caatinga. Documento para discussão no GT estratégias para uso sustentável.

Empresa Pernambucana de Pesquisa Agropecuária. 2003 [accessed 05 October 2005]. www.ipa.br

Ferraz, J.S.F., I.M.J. Meunier \& U.P. Albuquerque. 2005. Conhecimento sobre espécies lenhosas úteis da mata ciliar do Riacho do Navio, Floresta, Pernambuco. Zonas Áridas 9:27-39.

Ferraz, J.S.F., U.P. Albuquerque \& I.M.J Meunier. 2006. Valor do uso e estrutura da vegetação lenhosa às margens do Riacho do Navio, Floresta, PE, Brasil. Acta Botanica Brasílica 20:125-134. 


\section{de Lucena et al. - Local Uses of Native Plants in an Area of Caatinga Vegetation (Pernambuco, NE Brazil)}

Florentino, A.T.N., E.L. Araujo \& U.P. Albuquerque. 2007. Contribuição de quintais agroflorestais na conservação de plantas da Caatinga, Município de Caruaru, PE, Brasil. Acta Botanica Brasílica 21:37-47.

Galeano, G. 2000. Forest use at the Pacific Coast of Chocó, Colombia: A quantitative approach. Economic Botany 54:358-376.

Gomez-Beloz, A. 2002. Plant use knowledge of the Winikina Warao: the case for questionnaires in ethnobotany. Economic Botany 56:231-241.

Hoffman, B. \& T. Gallaher. 2007. Importance Indices in Ethnobotany. Ethnobotany Research \& Applications 5: 201-218.

IBGE - Instituto Brasileiro de Geografia e Estatística. 2000. Censo demográfico [accessed 15 March 2005]. www.ibge.gov.br

Luoga, E.J., E.T.F. Witkowski \& K. Balkwill. 2000. Differential utilization and ethnobotany of trees in Kitulanghalo Forest Reserve and surrounding communal lands, Eastern Tanzania. Economic Botany 54:328-343.

Lucena, R.F.P., U.P. Albuquerque, J.M. Monteiro, C.F.C.B.R. Almeida, A.T.N. Florentino \& J.S.F. Ferraz. 2007a. Useful of the semi-arid northeastern region of Brazil - a look at their conservation and sustainable use. Environmental Monitoring and Assessment 125:281-290.

Lucena, R.F.P., E.L. de Araújo \& U.P. Albuquerque. 2007b. Does the local availability of woody caatinga plants (Northeastern Brazil) explain their use value? Economic Botany 61:347-361.

Monteiro, J.M., U.P. Albuquerque, E.M.F. Lins-Neto, E.L. Araújo \& E.L.C. Amorim. 2006a. Use patterns and knowledge of medicinal species among two rural communities in Brazil's semi-arid northeastern region. Journal of Ethnopharmacology 105:173-186.

Monteiro, J.M., C.F.C.B.R. Almeida, U.P. Albuquerque, R.F.P. Lucena, A.T.N. Florentino \& R.L.C. Oliveira 2006b. Use and traditional management of Anadenanthera colubrina (Vell.) Brenan in the semi-arid region of northeastern Brazil. Journal of Ethnobiology and Ethnomedicine 2:1-7.

Mutchnick, P.A. \& B.C. McCarthy.1997. An ethnobotanical analysis of the tree species common to the subtropical moist forests of the Petén, Guatemala. Economic Botany 51:158-183.

Nascimento, V.T. 2007. Estratégias rurais de uso e manejo de plantas para a construção de cercas em uma área de caatinga no município de Caruaru, Pernambuco. Dissertação. Recife, PE, Brasil.
Oliveira, R.L.C., E.M.F. Lins Neto, E.L. Araújo \& U.P. Albuquerque. 2007. Conservation priorities and populations structure of woody medicinal plants in an area of Caatinga Vegetation (Pernambuco State, NE Brazil). Environmental Monitoring and Assessment 132:189-206.

Phillips, O. \& A.H. Gentry. 1993a. The useful plants of Tambopata, Peru: I. Statistical hypothesis tests with a new quantitative technique. Economic Botany 47:15-32.

Phillips, O. \& A.H. Gentry. 1993b. The useful plants of Tambopata, Peru: II. Additional hypothesis testing in quantitative ethnobotany. Economic Botany 47:33-43.

Phillips, O., A.H. Gentry, P. Wilkin \& B. Gálvez-Durand. 1994. Quantitative ethnobotany and Amazonian conservation. Conservation Biology 8:225-248.

Ramos, M.A., P.M. Medeiros, A.L.S. Almeida, A.L.P. Feliciano \& U.P. Albuquerque. 2008a. Use and knowledge of fuelwood in an area of caatinga vegetation in NE, Brazil. Biomass \& Bioenergy (in press.). doi:10.1016/j. biombioe.2007.11.015.

Ramos, M.A., P.M. Medeiros, A.L.S. Almeida, A.L.P. Feliciano \& U.P. Albuquerque. 2008b. Can wood quality justify local preferences for firewood in an area of caatinga (dryland) vegetation. Biomass \& Bioenergy (in-press). doi:10.1016/j.biombioe.2007.11.010.

Rossato, S.C., H.F. Leitão-Filho \& A. Begossi. 1999. Ethnobotany of Caiçaras of the Atlantic Forest Coast (Brazil). Economic Botany 53:387-395.

Silva, V.A. \& U.P. Albuquerque. 2004. Técnicas para análise de dados etnobotânicos. Pp. 63-88 in Métodos e técnicas na pesquisa etnobotânica. Edited by U.P. Albuquerque \& R.F.P. Lucena. Editora NUPEEA. Recife, Brasil.

Tacher, S.I.L., J.R.A. Rivera, M.M.M. Romero \& A.D. Fernández. 2002. Caracterización del uso tradicional de la flora espontánea en la comunidad Lacandona da Lacanhá, Chiapas, México. Interciencia 27: 512-520.

Toledo, V.M., A.I. Batis, R. Bacerra, E. Martinez \& C.H. Ramos. 1995. La selva útil: Etnobotânica cuantitativa de los grupos indígenas del trópico úmido de México. Interciencia 20:177-187.

Voeks, R.A. 1996. Tropical forest healers and habitat preference. Economic Botany 50:381-400. 
